\title{
Survival of Legionella pneumophila in a Model Hot Water Distribution System
}

\author{
By GERALDINE M. SCHOFIELD* AND A. E. WRIGHT \\ Environmental Microbiology and Safety Reference Laboratory, PHLS Centre for Applied \\ Microbiology and Research, Porton Down, Salisbury SP4 OJG, UK
}

(Received 26 January 1984)

A virulent strain of Legionella pneumophila was inoculated into an enclosed system supplied with unsterilized water from a domestic hot water supply. Growth of bacteria was monitored over 10 weeks. An increase in the number of organisms other than legionellas occurred but few amoebae were observed and none could be cultured. Viable counts of $L$. pneumophila in the circulation fluid decreased slightly. However, particles of debris which accumulated in the apparatus and which were stained by the indirect fluorescent antibody technique were found to be almost totally composed of $L$. pneumophila. On dismantling the apparatus Legionella was isolated in moderately high numbers from several different types of surfaces, particularly natural rubber and silicone.

\section{INTRODUCTION}

Direct isolation of Legionella sp. from environmental samples on to artificial media has only recently been successful (Dennis et al., 1983; Edelstein et al., 1982; Wadowsky \& Yee, 1981). Problems with in vitro cultivation on complex, nutrient-rich media brought into question the ability of legionellas to survive and grow in an aqueous environment in nutrient-poor conditions. The work of Bohach \& Snyder (1983), Pope et al. (1982) and Rowbotham $(1980,1983)$ gave rise to the idea that legionellas in their natural habitat perhaps grow in association with other microorganisms such as amoebae or cyanobacteria. In contrast Yee \& Wadowsky (1982) demonstrated that Legionella pneumophila could survive, and may multiply, in tap water. In addition, isolations of $L$. pneumophila have recently been made from showerheads and calorifiers (Best $e t$ al., 1983; Fisher-Hoch et al., 1982; Wadowsky et al., 1982) where the presence of amoebae or photosynthetic bacteria was doubtful. This paper describes an experiment devised to monitor the survival of $L$. pneumophila in such a situation, with no added nutrient source. An apparatus was constructed in which colonization of natural rubber and metals commonly found in a hot water distribution network could be examined.

\section{METHODS}

The apparatus devised is illustrated in Fig. 1. A water bath was constructed just large enough to accommodate a 1 litre conical flask which was to contain the starter inoculum of L. pneumophila. Water loss was minimized by covering the surface with polystyrene beads. Water coming from the flask was monitored by a flow meter (B); it was then divided into three tubes by a metal connector. Each piece of silicone tubing ( $4 \mathrm{~mm}$ diameter) passed through a separate channel of a peristaltic pump (Watson-Marlow Ltd, Falmouth, Cornwall, UK). The tubes each supplied one of three large glass chambers $(15 \times 4 \mathrm{~cm}$ diameter $)$ which were stoppered with rubber bungs. Chamber D contained $10 \mathrm{~cm}$ long twists of copper sheet [20 gauge C101 (BS 2870: 1968): copper 99.9\% minimum, lead $0.005 \%$, bismuth $0.001 \%$, total impurities $0.03 \%$ excluding oxygen and silver]. Chamber $\mathrm{E}$ contained $10 \mathrm{~cm}$ long twists of stainless steel sheet [ 20 gauge (EN . 58 . B, used for welded fabrications in the chemical, textile, dairy, brewery and catering industries): chromium $18 \%$, nickel $8 \%$, stabilized with titanium; Southern Aluminium

\footnotetext{
Abbreviations: BCYEA, buffered charcoal/yeast extract medium; GVPCA, legionella isolation agar; NA, nutrient agar.
} 
A

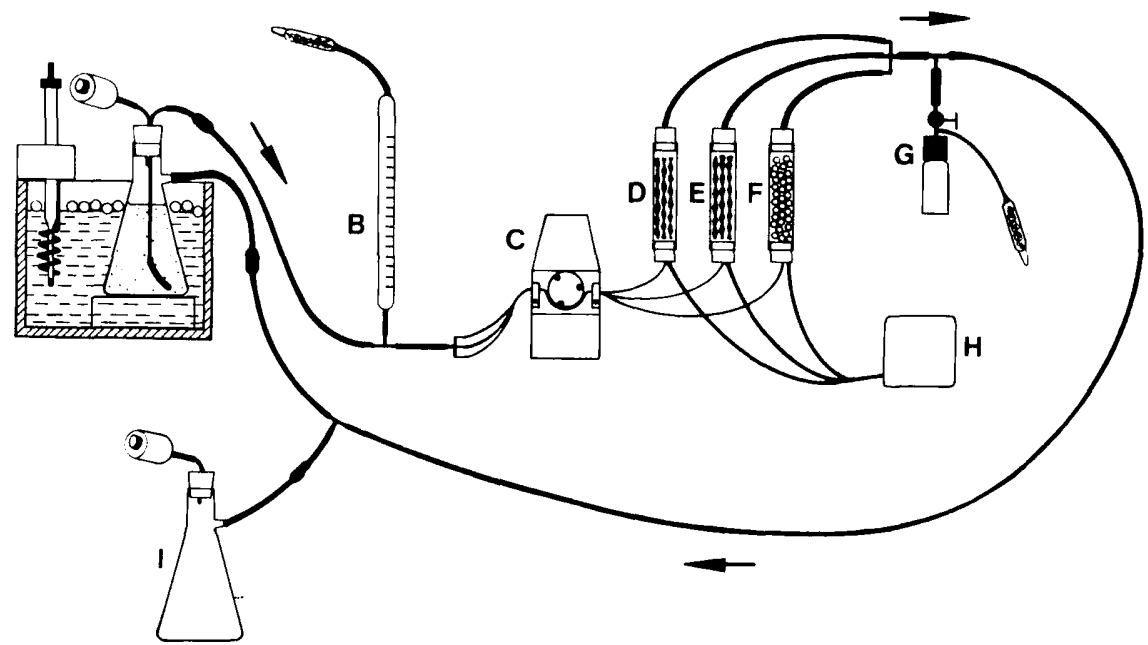

Fig. 1. Diagram of the model hot water system. A, water bath; B, flow meter; C, peristaltic pump; D, rubber-stoppered glass tube containing copper turnings; E, rubber-stoppered glass tube containing stainless steel turnings; F, rubber-stoppered glass tube containing glass beads and aluminium discs; $G$, sample port; H, air pump; I, return flask. All tubing was of silicone.

Supplies, Poole, Dorset, UK). Chamber F contained $5 \mathrm{~mm}$ diameter glass beads plus aluminium discs (BUO 14057, Balzers High Vacuum Ltd, Berkhamsted, UK). After passing through the glass chambers the fluid was combined and recirculated to the conical flask via a sample port $(G)$. A connection to provide all chambers with air $\mathrm{H}$ ) was available but this was used only once, for 30 min during the first week of the experiment. All connecting tubing was of silicone.

The system was seeded with a virulent strain of $L$. pneumophila serogroup 1 (74/81) (Hambleton et al., 1983). This strain was isolated from a naturally contaminated water supply and had been subcultured on artificial media a maximum of three times. A $5 \mathrm{~d}$ culture grown on buffered charcoal/yeast extract medium plus 2-oxoglutarate (BCYEA) (Edelstein, 1981) was used to inoculate $480 \mathrm{ml}$ sterile Pages' saline $\left(\mathrm{NaCl}^{\circ} \mathrm{O} \cdot 12 \mathrm{~g}\right.$, anhydrous $\mathrm{MgSO}_{4}$ $0.004 \mathrm{~g}, \mathrm{CaCl}_{2} .2 \mathrm{H}_{2} \mathrm{O} 0.004 \mathrm{~g}$, anhydrous $\mathrm{Na}_{2} \mathrm{HPO}_{4} 0.142 \mathrm{~g}, \mathrm{KH}_{2} \mathrm{PO}_{4} 0.136 \mathrm{~g}$, made up with 1 litre distilled water, $\mathrm{pH}$ 6.8-7.0) plus $500 \mathrm{ml}$ non-sterilized tap water from the hot water supply, contained in a 1 litre conical flask, final $\mathrm{pH} 7 \cdot 5$. A $4 \mathrm{ml}$ sample was removed for a chemical analysis and $1 \mathrm{ml}$ for a viable count. Tenfold dilutions were prepared and triplicate $0.1 \mathrm{ml}$ samples plated on to legionella isolation agar (GVPCA) (Dennis $e t$ al., 1983). The flask was placed in the water bath (A) at $45^{\circ} \mathrm{C}$ and the fluid subjected to a programme of intermittent circulation. This was chosen to reproduce the periods of movement and stagnation which commonly occur in a domestic hot water system. The inoculum was circulated through the system for $24 \mathrm{~h}$ at $690 \mathrm{ml} \mathrm{h}^{-1}$, and was left static for $2 \mathrm{~d}$ at ambient temperature before being run at the same speed at $45^{\circ} \mathrm{C}$ for a further $24 \mathrm{~h}$. After $3 \mathrm{~d}$ at room temperature, the water was slowly drained from the system into a collection vessel (I) and replaced by $750 \mathrm{ml}$ warm tap water direct from the domestic supply. Circulation of the fresh water was at $690 \mathrm{ml} \mathrm{h}^{-1}$ and $45^{\circ} \mathrm{C}$ for $8 \mathrm{~h}$, and at $690 \mathrm{ml} \mathrm{h}^{-1}$ at room temperature for $16 \mathrm{~h}$. The latter procedure was repeated once every week for the duration of the experiment. The water in the flask, which was reduced by weekly sampling, was kept at $750 \mathrm{ml}$ by the addition of warm tap water.

Four weeks after the start of the experiment and at each subsequent week $15 \mathrm{ml}$ water was flushed out of the system at $4 \mathrm{l} \mathrm{h}^{-1}$ into a glass universal container at the sample port (G). A drop of this was taken for direct microscopic observation, and $10 \mathrm{ml}$ of the sample was drawn through an Oxoid millipore filter $(0.45 \mu \mathrm{m})$ which was placed on to GVPCA. Tenfold dilutions were prepared in sterile distilled water and triplicate $0.1 \mathrm{ml}$ samples plated on to nutrient agar (NA) and GVPCA. In an attempt to cultivate any amoebae present in the water, lawns of UV-irradiated cells of Escherichia coli (Commune) were inoculated with water samples (Rowbotham, 1980).

Starting on the fourth week of the experiment macroscopic films of debris were often seen in the sample vessel (G). These were attached to microscope slides, dried, fixed for $10 \mathrm{~min}$ in methanol and either Gram-stained or treated with fluorescein-labelled antibody raised against $L$. pneumophila serogroup 1 . The antibody was prepared by inoculating rabbits with heat-killed cells of $L$. pneumophila serogroup $1(74 / 81)$. Unabsorbed antiserum at $1 / 100$ was used with sheep anti-rabbit conjugate (Wellcome) at $1 / 320$. The antibody was checked for its specificity against E. coli, Pseudomonas aeruginosa, Sarcina lutea, Staphylococcus aureus and L. pneumophila serogroups 2-6. 
No cross-reactions were seen at the working level of the antiserum. The indirect immunofluorescence technique used was that recommended by the Division of Microbiological Reagents and Quality Control, PHLS, Colindale, London, UK.

The whole experiment was terminated after 10 weeks; water was drained from the system into screw-capped bottles, $5 \mathrm{ml}$ was taken for a chemical analysis and the apparatus was dismantled. Areas of the copper and stainless steel turnings $\left(1 \mathrm{~cm}^{2}\right)$ were scraped with a sterile scalpel and any material obtained was emulsified in $2 \mathrm{ml}$ sterile distilled water and triplicate $0.1 \mathrm{ml}$ samples were plated on to NA, BCYEA and GVPCA. Whole pieces $\left(7 \mathrm{~cm}^{2}\right)$ of the metal turnings, portions of the silicone tubing $(3.0 \times 0.4 \mathrm{~cm}$ diameter $)$, portions of the rubber bung $\left(1 \mathrm{~cm}^{2}\right)$ and five glass beads ( $5 \mathrm{~mm}$ diameter) were each immersed in $9 \mathrm{ml}$ sterile distilled water in a screw-capped bottle. After $1 \mathrm{~h}$ they were shaken for $1 \mathrm{~min}$ on a Whirlimixer (Fisons Scientific), tenfold dilutions were prepared and triplicate $0.1 \mathrm{ml}$ samples plated on to NA, BCYEA and GVPCA. Small pieces of tubing together with ten glass beads were pressed directly on to NA and GVPCA. All plates were incubated at $37^{\circ} \mathrm{C}$ for up to $17 \mathrm{~d}$.

Colonies which appeared after $5 \mathrm{~d}$ on GVPCA and had a characteristic cut-glass appearance were presumptively identified as $L$. pneumophila. They were subcultured on GVPCA and on a medium which did not contain L-cysteine or ferric pyrophosphate - growth on this negative control medium excluded the possibility of Legionella. Confirmation of $L$. pneumophila was by the indirect immunofluorescent method previously described. Other isolates were tentatively identified using standard biochemical methods (Cowan \& Steel, 1974). A Leitz Dialux 20 EB microscope was used for transmitted light, fluorescence microscopy and photography.

\section{RESULTS}

The inoculum contained $3 \times 10^{4}$ cells of $L$. pneumophila serogroup $1 \mathrm{ml}^{-1}$. A $10 \mathrm{ml}$ sample of the inoculated hot water was examined for the presence of legionellas, but none were detected. However, the calorifier supplying the water contained, in a 5 litre sample, approximately $10^{4}$ cells of L. pneumophila serogroup 1 (P. J. Dennis, personal communication). Plate counts for the six weekly samples are shown in Table 1 . The numbers of legionellas isolated were fairly stable over nine weeks while the non-legionellas appeared to be slowly increasing in number. Motile and non-motile rods were observed in the water samples examined by dark-field microscopy. Single amoebae were seen only twice and none could be cultured on the killed lawns of $E$. coli.

During the fifth week a relatively large piece of filmy material, which roughly conformed to the circular shape of the tubing, appeared in the glass sample vessel (Fig. $2 a$ ). This material was cut into three; two pieces were affixed to microscope slides for staining, and the other portion was macerated in $2 \mathrm{ml}$ sterile distilled water and plated on to NA and GVCPA. The counts were 24 c.f.u. on NA and $4.4 \times 10^{4}$ c.f.u. on GVCPA. In the stained film many Gram-negative cells appeared to be embedded in an amorphous lightly stained background. Metal oxides, crystal structures and other debris were also present. The duplicate sample, which was stained with fluorescein-labelled antibody, showed it was composed almost entirely of L. pneumophila serogroup 1 (Fig. $2 b$ ). In Fig. $2(b)$ a microcolony as well as individual cells is clearly visible. On the ninth week of sampling another similar piece of debris was flushed into the sample port (Fig.

Table 1. Viable counts of bacteria isolated from a model hot water distribution system inoculated with Legionella pneumophila

$\begin{array}{clcc}\begin{array}{c}\text { Weeks post- } \\ \text { inoculation }\end{array} & \text { Sample point } & \overbrace{\begin{array}{c}\text { NA } \\ \text { Non-legionella }\end{array}}^{\text {No. of bacteria (ml water) }}{ }^{-1} & \begin{array}{c}\text { GVPCA } \\ \text { Legionella }\end{array} \\ 0 & \text { Inoculation flask } & 0 & 30000 \\ 4 & \text { Inoculum flask } & 900 & 17000 \\ & \text { Sample port } & 1800 & 15000 \\ 5 & \text { Inoculum flask } & \text { ND } & 2350 \\ 6 & \text { Sample port } & 200 & 2600 \\ 7 & \text { Sample port } & 2700 & 1700 \\ 9 & \text { Sample port } & \text { ND } & 12000 \\ & \text { Sample port } & 8000 & 4100 \\ & & & \end{array}$



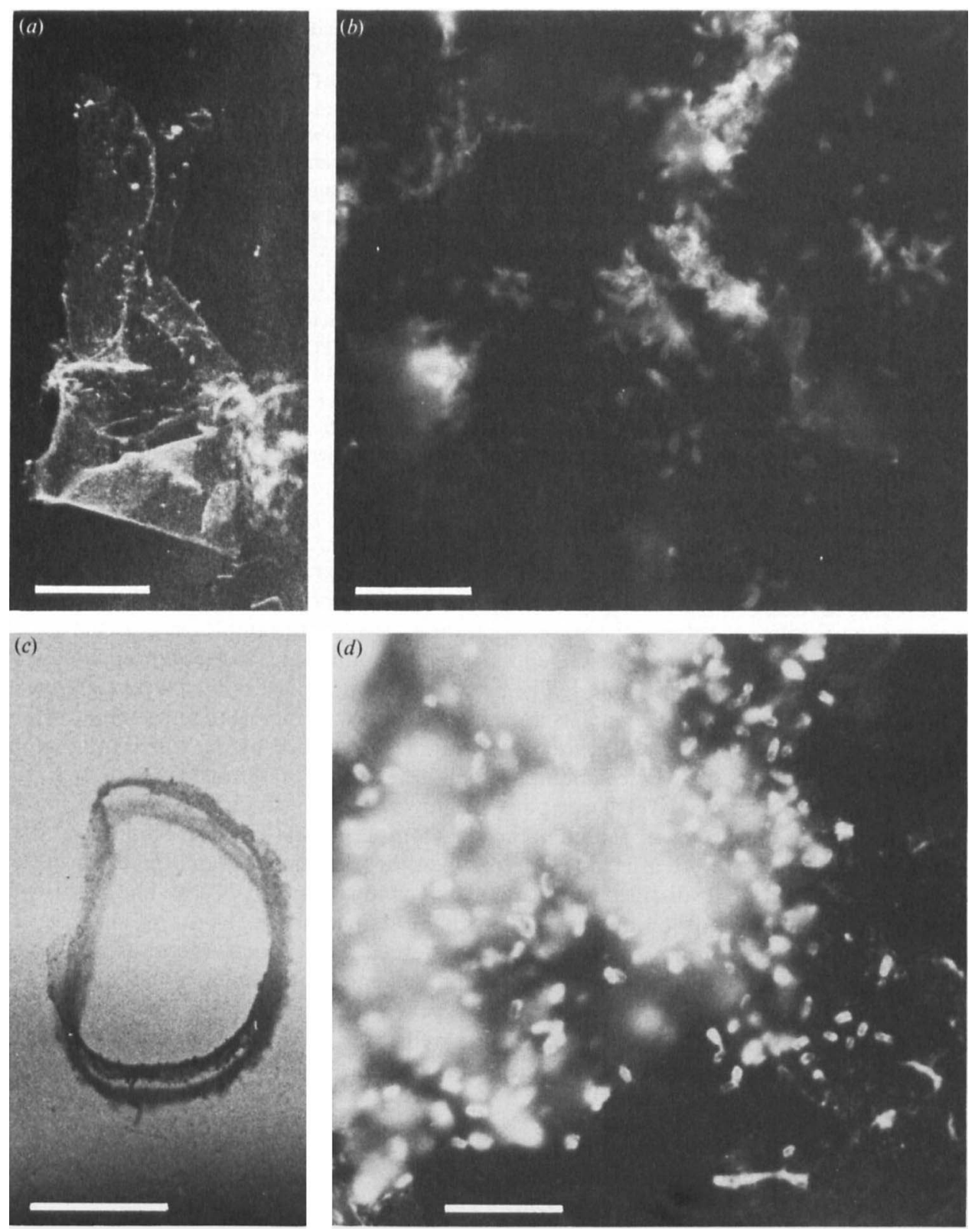

Fig. 2. (a) Debris washed out of the system into the glass sample vessel four weeks post-inoculation. Bar marker, $2.5 \mathrm{~mm}$. (b) Fluorescein-labelled antibody stain of the debris in (a) showing microcolonies and individual cells of L. pneumophila. Bar marker, $10 \mu \mathrm{m}$. (c) Debris washed out of the system into the sample vessel nine weeks post-inoculation. Bar marker, $2 \mathrm{~mm}$. (d) Fluorescein-labelled antibody stain of the debris in $(c)$ showing clumps and individual cells of $L$. pneumophila. Bar marker, $10 \mu \mathrm{m}$.

$2 c$ ). When treated with antibodies it was seen to contain large numbers of $L$. pneumophila (Fig. $2 d$ ). The viable count from a small piece, approximately one-quarter, was: L. pneumophila $5 \cdot 1 \times$ $10^{3}$ c.f.u., non-legionellas 76 c.f.u.

The $\mathrm{pH}$ of the water after nine weeks was $7 \cdot 3$ and the chemical analyses showed an increase in the amount of iron from less than 0.1 at the start to 1.0 p.p.m. and a decrease in the copper content from $0 \cdot 16$ to $0 \cdot 11$ p.p.m. 
Table 2. Viable counts of bacteria from components of a model hot water system 10 weeks after inoculation with L. pneumophila

\begin{tabular}{|c|c|c|c|c|}
\hline Component (area) & Medium & $\begin{array}{c}\text { NA } \\
\text { Non-legionella }\end{array}$ & $\begin{array}{c}\text { BCYEA } \\
\text { Non-legionella }\end{array}$ & $\begin{array}{c}\text { GVCPA } \\
\text { Legionella } \\
\text { pneumophilo }\end{array}$ \\
\hline e tubing $\left(4.5 \mathrm{~cm}^{2}\right)$ & & 450 & 200 & 5400 \\
\hline beads $\left(12.5 \mathrm{~cm}^{2}\right)$ & & 900 & 300 & 900 \\
\hline bung $\left(1 \mathrm{~cm}^{2}\right)$ & & 32 & 32 & 12000 \\
\hline turning $\left(7 \mathrm{~cm}^{2}\right)$ & & 0 & 170 & 2 \\
\hline $\mathrm{g}$ from copper $\left(1 \mathrm{~cm}^{2}\right)$ & & 0 & 0 & 0 \\
\hline s steel turning $\left(7 \mathrm{~cm}^{2}\right)$ & & 0 & 400 & 1000 \\
\hline $\mathrm{g}$ from steel $\left(1 \mathrm{~cm}^{2}\right)$ & & 0 & 87 & 53 \\
\hline
\end{tabular}

When the apparatus was dismantled L. pneumophila was isolated from all areas (Table 2). Highest counts were from the rubber bung scrapings and lowest from the copper turnings. A random sample of 36 non-legionella-like colonies was picked off the NA plates and purified. These all fell into one of four groups according to colony, cell morphology and Gram reaction. One group of aerobic, Gram-positive, spore-forming rods probably consisted of members of the genus Bacillus. The other three groups contained Gram-negative, catalase- and oxidase-positive rods which showed an oxidative breakdown of carbohydrates. Representatives of all four groups did not cross-react with the L. pneumophila serogroup 1 antiserum.

\section{DISCUSSION}

The system was not kept sterile during its assembly. The hot water supply was chosen because of the absence of free chlorine and was not sterilized because Legionella sp. do not appear to survive well in sterilized tap water (Yee \& Wadowsky, 1982).

The removal of the inoculum containing $3.4 \times 10^{4} \mathrm{~L}$. pneumophila $\mathrm{ml}^{-1}$ after $7 \mathrm{~d}$ did not greatly affect the count. The number of viable legionellas in the circulating fluid during weeks 4 9 of the experiment varied between $1.7 \times 10^{4}$ and $2.35 \times 10^{3} \mathrm{ml}^{-1}$. However, these weekly viable counts from the water cannot reflect the numbers of bacteria possibly present on the various surfaces. There was a macroscopic build-up of debris within the apparatus, bits of which were occasionally washed into the sample vessel. The Gram stain, viable count and fluorescence studies of these films of debris clearly showed that they consisted of large numbers of bacteria and that most of those were $L$. pneumophila serogroup 1 . The deposits removed by washing the surfaces of the silicone, glass, steel and rubber also contained L. pneumophila. The deposit on $1 \mathrm{~cm}^{2}$ of the surface of one of the six rubber bungs contained $1.2 \times 10^{4}$ cells of L. pneumophila (Table 2), approximately equivalent to $1.4 \times 10^{6}$ on the entire surface. The original seed of $L$. pneumophila was circulated around the system for a total of $48 \mathrm{~h}$. It seems doubtful that this inoculum alone could account for the large numbers of $L$. pneumophila observed in the film-like deposits and on the surfaces of the components of the system. During those first $48 \mathrm{~h}$ either many cells adhered to the surfaces and to each other so forming clumps or there was some growth and division which produced the mat of cells so often observed.

As no enrichments were supplied any organism growing in the system did so in very nutrientpoor conditions. A minor food resource could have been provided by the other micro-organisms present in the system. However, amino acids are a primary nutrient requirement for Legionella sp. (Tesh et al., 1983), but exactly from where these were supplied can only be a matter of conjecture. Iron salts are also a growth requirement and the chemical analysis showed an increase in iron content during the 10 week experimental period. This increase was probably caused by the continual topping-up of the water bath flask from the domestic hot water supply. The decrease in copper content was perhaps due to the formation of oxides - green discolouration of the copper turnings was observed during the course of the experiment. 
It has been suggested that legionellas require other organisms with which to live in association and that the most likely hosts are amoebae (Rowbotham, 1980, 1983). However, few amoebae were present in this system and the numbers observed do not suggest that they could either provide the extracellular growth factors needed or an intracellular habitat. Tyndall \& Domingue (1982), after an inconclusive study, thought that free-living amoebae might provide a necessary niche only in an otherwise unfavourable environment. The micro-environment produced in this apparatus during the course of the experiment did appear to be favourable, permitting survival and possibly growth of a virulent strain of $L$. pneumophila.

The strain of Legionella pneumophila and the fluorescein-labelled antibody were provided by Mr P. J. Dennis; the photographic work was by $\mathrm{Mr} \mathrm{S}$. Clark and the technical assistance of Mr T. A. Collinge was invaluable in the design of the apparatus.

\section{REFERENCES}

Best, M., Stout, J., Muder, R. R., Yu, V., Goetz, A. \& TAYLOR, F. (1983). Epidemiological link with disease and evaluation of a method for control of nosocomial Legionnaires' disease and Pittsburgh pneumonia. Lancet ii, no. 8345, 307-310.

BOHACH, G. A. \& SNYDER, I. S. (1983). Cyanobacterial stimulation of growth and oxygen uptake by Legionella pneumophila. Applied and Environmental Microbiology 46, 528-531.

Cowan, S. T. \& STEEL, K. J. (1974). Manual for the Identification of Medical Bacteria. Cambridge \& London: Cambridge University Press.

Dennis, P. J., Bartlett, C. L. R. \& Wright, A. E. (1983). A comparison of isolation methods for Legionellaceae. In Proceedings of 2nd International Symposium on Legionella, pp. 294-296. Washington: American Society for Microbiology.

EDELSTEIN, P. H. (1981). Improved semiselective medium for isolation of Legionella pneumophila from contaminated clinical and environmental specimens. Journal of Clinical Microbiology 14, 298-303.

Edelstein, P. H., Snitzer, J. B. \& Finegold, S. M. (1982). Isolation of Legionella pneumophila from hospital potable water specimens: comparison of direct plating with guinea pig inoculation. Journal of Clinical Microbiology 15, 1092-1096.

Fisher-Hoch, S. P., SMith, M. G. \& Colbourne, J. S. (1982). Legionella pneumophila in hospital hot-water cylinders. Lancet $i$, no. 8338, 1073.

Hambleton, P., Broster, M. G., Dennis, P. J., Henstridge, R., Fitzgeorge, R. \& Conlan, J. W. (1983). Survival of virulent Legionella pneumophila in aerosols. Journal of Hygiene 90, 451-460.
Pope, D. H., SoraCco, R. J. \& Gill, H. K. (1982). Growth of Legionella pneumophila in two-membered cultures with green algae and cyanobacteria. Current Microbiology 7, 319-322.

Rowbotham, T. J. (1980). A preliminary report on the pathogenicity of Legionella pneumophila for freshwater and soil amoebae. Journal of Clinical Pathology 33, 1179-1183.

RowBothaм, T. J. (1983). Isolation of Legionella pneumophila from clinical specimens via amoebae, and the interaction of those and other isolates with amoebae. Journal of Clinical Pathology 36, 978-986.

TESH, M. J., MoRse, S. A. \& Miller, R. D. (1983). Intermediary metabolism in Legionella pneumophila: utilization of amino acids and other compounds as energy sources. Journal of Bacteriology 154, 11041109.

Tyndall, R. L. \& Domingue, E. L. (1982). Cocultivation of Legionella pneumophila and free-living amoebae. Applied and Environmental Microbiology 44, 954959.

W ADOWSKy, R. M. \& YeE, R. B. (1981). A glycinecontaining selective medium for isolation of Legionellaceae from environmental specimens. Applied and Environmental Microbiology 42, 768-772.

Wadowsky, R. M., Yee, R. B., Mezmar, L., Wing, E. J. \& Dowling, J. N. (1982). Hot water systems as sources of Legionella pneumophila in hospital and nonhospital plumbing fixtures. Applied and Environmental Microbiology 43, 1104-1110.

YEE, R. B. \& WADOWSKY, R. M. (1982). Multiplication of Legionella pneumophila in unsterilized tap water. Applied and Environmental Microbiology 43, 13301334. 